\title{
Correlation and Path Coefficient Analysis of Seed Yield and Yield Components of French Bean (Phaseolus vulgaris L.) Genotypes in Sub-tropical Region
}

\begin{abstract}
Santosh Kalauni,a,*, Deependra Dhakal ${ }^{2, b}$
${ }^{1}$ Horticulture Research Station, Dailekh, Nepal

${ }^{2}$ Gokuleshwor Agriculture and Animal Science College, Baitadi, Nepal

*Corresponding author

A R T I C L E I F O A B S T R A C T

Research Article

Received : 23/04/2020

Accepted : 11/08/2020

Keywords:

French bean

Individual pod weight

Multivariate

Path coefficient

Regression

This research aims to determine the relationship between yield and yield components of French bean using multivariate statistical techniques. The study was conducted at Horticulture Research Station, Dailekh, Nepal for consecutive three year of 2016-2018. In this study, six French bean genotypes were used. The following measurements and observations were made: germination (\%), pod length $(\mathrm{cm})$, pod diameter $(\mathrm{mm})$, individual pod weight and number of seeds pod $^{-1}$, number of dry pods plant $\mathrm{t}^{-1}$, dry pod yield plant ${ }^{-1}$ and dry pod yield $(\mathrm{t} / \mathrm{ha}), 100$ seed weight $(\mathrm{g})$ and seed yield (t/ha). Highly significant and positive correlation was recorded between seed yield and individual pod weight $\left(\mathrm{r}=0.659^{* * *}\right)$, number of seed $\operatorname{pod}^{-1}\left(\mathrm{r}=0.548^{* *}\right)$ and pod length $\left(0.459^{*}\right)$. Conversely, pod diameter showed a negative and non-significant $(-0.025)$ correlation on seed yield. Based on simple regression analysis, linear regression of individual pod weight, number of seed pod $^{-1}$ and pod length leads to an increase in the seed yield ( $\mathrm{t} / \mathrm{ha}$ ) by $0.188,0.285$ and 0.103 units respectively. From the path coefficient analysis maximum positive direct effect on seed yield was recorded by number of seeds $\operatorname{pod}^{-1}(0.767)$ followed by 100 seed weight $(0.530)$ and individual pod weight (0.429). Also, stepwise multiple linear regression analysis revealed that three traits individual pod weight, 100 seed weight and number of dry pod plant- 1 account for $68.22 \%$ of the total variation in seed yield, while only $31.78 \%$ was explained by rest of the variables. Summarizing outcomes of four statistical methods showed that individual pod weight appeared to be the most effective contributor of seed yield followed by the number of seed pod $^{-1}, 100$ seed weight, and pod length. Therefore, focus should be laid on these characters in future breeding program while selecting genotypes for sub-tropics for improving the seed yield.
\end{abstract}

santoshkalauni11@gmail.com

(D) https://orcid.org/0000-0003-2014-9315

|b@ddhakal.rookie@gmail.com

Ditps://orcid.org/0000-0002-0347-7950

(c) (1) (9) This work is licensed under Creative Commons Attribution 4.0 International License

\section{Introduction}

French bean (Phaseolus vulgaris), commonly known as common bean, snap bean or kidney bean is a widely grown leguminous self-pollinated crop $(2 n=2 x=22)$. French bean is valued for its nutritional composition (high protein content in dry bean and good fiber source in snap bean) and market value. It is one of the most principal legume crops worldwide for human consumption. In Nepal, it is cultivated in diverse agro-climatic conditions ranging from terrain at $300 \mathrm{~m}$ above mean sea level to high hills at 2,500 $\mathrm{m}$ above mean sea level in different seasons (Neupane et al., 2008). It is mostly cultivated for its tender/immature pods as vegetable and dried seeds used as pulse. The total cultivated area and production of dry bean in Nepal is around 22510 ha and 19.386 thousand tones (FAO, 2017).

In a crop improvement program yield enhancement is the most important breeding objective for most of the breeders (Ghobary and Abd-Allah, 2010). Seed yield is a complex dependent character with low heritability governed by various genes and environmental factors as well by morphological and physiological traits. The use of selection criteria that determines the direct relationship of yield components with seed yield helps to increase the success of plant breeding (Karasu and Oz, 2010). Correlation analysis merely describes the relationship between traits but does not provide the direct and indirect effects with related traits. On the contrary, path analysis counts for a measure of relative importance of each independent (explanatory) variable to predict the changes in the dependent (response) one (Ojha et al., 2018). Individual components of yield may affect yield directly and/or indirectly by influencing other components produced in the later stage of development (Doust et al., 1983).

The selection of genotypes based on their variability is the core to the success of crop breeding. Therefore, it is essential to study the genetic information that exist in a population of dry bean (Raffi and Nath, 2004). Previously, several researchers have carried out a study on variability and interrelationship of characters in dry bean (Goncalves et al., 
2003; Singh and Singh, 2013; Akhshi et al., 2015; Ambachew et al., 2015; Ejara et al., 2017; Goncalves et al., 2017; Panchbhaiya et al., 2017). This study was performed to estimate the correlation of each variable, learn the direct and indirect effects of yield components on seed yield and determining the statistical method for the effective selection of yield components in dry bean breeding for higher yield.

\section{Materials and Methods}

\section{Experimental Site and Plant Materials}

The present investigation was carried out at the experimental farm of Horticulture Research Station (HRS), Dailekh during the three successive seasons during the 2016-2018 periods. The station is located at a latitude of $28^{\circ} 13^{\prime} 6.18^{\prime \prime} \mathrm{N}$ and longitude of $83^{\circ} 58^{\prime} 27.72$ ' $\mathrm{E}$ and characterized by subtropical climate with an elevation of $1300 \mathrm{~m}$ above mean sea level. The experiment materials consist of six genotypes namely Bhatte, Chaumase, Dhankute Chirrke, WP Con Bean, White OP and, Trishuli (check). These genotypes were used as treatments and evaluated in the study.

\section{Layout and Experimental Design}

The present study was laid out in Randomized Complete Block Design (RCBD) with six genotypes and four replications. Each replication was maintained in a four-row plot of $3 \mathrm{~m}$ length and $2 \mathrm{~m}$ width with $25 \mathrm{~cm}$ plant to plant distance. The net experimental plot area was $2.25 \mathrm{~m}^{2}$.

\section{Cultural Practices}

Seeds of given genotypes were sown in between $18^{\text {th }}$ $28^{\text {th }}$ August for the three successive seasons. Two seeds were placed at each hill which was thinned later on after full emergence. Gap filling was carried out after the $8^{\text {th }}$ day of sowing and 32 plants were maintained in each plot. All the treatments were subjected to a recommended package of agronomic and plant protection practices to obtain a healthy crop. Manure and fertilizer were applied as compost $\left(20\right.$ tha $^{-1}$ ) and 40:60:50 $\mathrm{kg} \mathrm{ha}^{-1} \mathrm{~N}, \mathrm{P}$, and $\mathrm{K}$ respectively.

\section{Recording of Observations}

Within the plot, six plants were randomly taken and tagged for recording observations. Data were recorded on germination $(\%)$ at the time of plant establishment, pod length $(\mathrm{cm})$, pod diameter $(\mathrm{mm})$, individual pod weight and number of seeds pod $^{-1}$ during the marketable harvest and number of dry pods plant ${ }^{-1}$, dry pod yield plant ${ }^{-1}$ and dry pod yield $\left(\right.$ tha $\left.^{-1}\right), 100$ seed weight $(\mathrm{g})$ and seed yield $\left(\mathrm{tha}^{-1}\right)$ when pods start to ripen on the plant until dried and beginning to become brown in color.

\section{Statistical Analysis and Interpretation of Data}

\section{Descriptive analysis}

The three-year data was compiled taking the means of sample plants taken for each treatment and replication for different traits. The pooled means of three years were subjected to further statistical and biometrical analysis. Simple statistical estimates, viz. average, range, standard error and coefficient of variation were analyzed to screen traits for use in regression analysis, in accordance with Steel et al. (1997).

\section{Analysis of variance}

The three-year data were subjected to analysis of variance (ANOVA) with model specification for the randomized complete block design through $\mathrm{R}$ studio 3.1.1.

The linear model of observations in RCBD is of the form:

$$
\mathrm{y}_{\mathrm{ij}}=\mu+\mathrm{T}_{\mathrm{i}}+\beta_{\mathrm{j}}+\varepsilon_{\mathrm{ij}}
$$

Here,

$y_{i j} \quad$ Denotes the value of the observed trait for $i$

treatment received in the $\mathrm{j}$-th block,

$\mathrm{T}_{\mathrm{i}} \quad$ Represent the effect of treatment $\mathrm{i}(\mathrm{i}=1, \ldots, \mathrm{t})$,

$\beta_{j}$ Represent the effect of block/replication $\mathrm{j}(\mathrm{j}=1, \ldots, \mathrm{r})$

$\varepsilon_{\mathrm{ij}}$ İs an experimental error associated with the observation of the i-th treatment and j-th block.

\section{Simple correlation and regression coefficients}

To obtain the relationships between seed yield and yield components accurately, simple correlation and regression analysis was performed for all traits using Microsoft Excel. The data collected for the three years were combined then subjected to estimate correlation and regression coefficients among measured characteristics.

Path coefficient analysis

Path coefficient analysis was calculated based on phenotypic correlation coefficients taking seed yield as effect and other traits as cause. Direct and indirect effects of component characters on seed yield were worked out using path coefficient analysis using $\mathrm{R}$ studio 3.1.1.

Stepwise multiple linear regression

Stepwise multiple linear regression method was used to measure the variable that accounts for the majority of total yield variability. Stepwise multiple linear regressions were calculated using MINITAB 19 software statistical package. These multivariate procedures were applied to the mean data of three consecutive years including plant characteristics namely: germination $(\%)\left(\mathrm{x}_{1}\right)$, pod length $(\mathrm{cm})\left(\mathrm{x}_{2}\right)$, pod diameter $(\mathrm{mm})\left(\mathrm{x}_{3}\right)$, individual pod weight $\left(\mathrm{x}_{4}\right)$, number of seeds $\operatorname{pod}^{-1}\left(\mathrm{x}_{5}\right)$, number of dry pods plant ${ }^{-}$ ${ }^{1}\left(\mathrm{x}_{6}\right)$, dry pod yield plant ${ }^{-1}\left(\mathrm{x}_{7}\right), 100$ seed weight $(\mathrm{g})\left(\mathrm{x}_{8}\right)$ and seed yield (t/ha) $(\mathrm{y})$.

Table 1. Variance compoents estimation in analysis of variance for Randomized Complete Block Design (RCBD) with single treatment factor.

\begin{tabular}{l|cccc}
\hline \multicolumn{1}{c|}{ Source of variation } & Degrees of freedom & Sum of squares & Mean Squares & F \\
\hline Blocks/Replication & $\mathrm{r}-1$ & $\mathrm{SSB}$ & $\mathrm{SSB} /(\mathrm{r}-1)$ & \\
Treatments & $\mathrm{t}-1$ & $\mathrm{SST}$ & $\mathrm{SST} /(\mathrm{t}-1)$ & MST/MSE \\
Errors & $(\mathrm{r}-1)(\mathrm{t}-1)$ & $\mathrm{SSE}$ & $\mathrm{SSE} /(\mathrm{r}-1)(\mathrm{t}-1)$ & \\
\hline Total & $\mathrm{rt}-1$ & $\mathrm{TSS}$ & & \\
\hline
\end{tabular}

Form of analysis of variance for Randomized Completely Block (RCB) design 


\section{Results and Discussion}

Means of French Bean Yield and Its Components

The descriptive statistics of mean values, standard error, minimum and maximum values and coefficient of variation for six cultivars under study and selected traits are presented in (Table 2). In the present investigation, there was a considerable variation for all the characteristics. The results presented in Table 2 shows that coefficient of variation was highest for seed yield (t/ha), followed by 100 seed weight, number of dry podplant ${ }^{-1}$ and dry pod yield plant $^{-1}$. Germination (\%) recorded the lowest value followed by pod diameter while pod length, individual pod weight and number of seeds pod $^{-1}$ obtained moderate values for the coefficient of variation (Table 2 ).

The mean value of seed yield varied between $0.78 \mathrm{t} / \mathrm{ha}$ to $3.31 \mathrm{t} / \mathrm{ha}$. Germination percentage ranged from $79.16 \%$ to $95.83 \%$. The pod length was between $10.94 \mathrm{~cm}$ and $20.14 \mathrm{~cm}$, whereas pod diameter was between $9.07 \mathrm{~mm}$ and
$12.14 \mathrm{~mm}$. Ranges for individual pod weight, number of seed pod $^{-1}$, number of dry pod plant ${ }^{-1}$, dry pod yield plant ${ }^{1}$ and 100 seed weight were between $8.29 \mathrm{~g}$ and $16.16 \mathrm{~g}, 4.8$ and $8.35,25.93$ and $67.0,59.99 \mathrm{~g}$ and $180.6 \mathrm{~g}$ and $20.75 \mathrm{~g}$ to $64.13 \mathrm{~g}$ respectively (Table 2 ).

Seed yield, 100 seed weight, dry pod yield plant ${ }^{-1}$ and number of dry pod plant ${ }^{-1}$ showed the existence of high variation among the studied traits. These results were supported by Nimbalkar et al. (2002) who obtained the highest phenotypic coefficient of variation for 100 seed weight. In the study of genetic variability and relationship of yield and yield contributing characters, Raffi and Nath (2004) observed the same results in dry beans (Phaseolus vulgaris). The significant variation in some of the studied traits indicates the possibility of their use in the breeding programs.

Table 2. Basic statistical parameters for yield and yield components in French bean: mean values, standard error, minimum values (Min) maximum values (Max) and coefficient of variation (CV)

\begin{tabular}{l|rrrrr}
\hline \multicolumn{1}{c|}{ Character } & Mean & SE & Min. & Max. & CV\% \\
\hline Germination $(\%)\left(\mathrm{x}_{1}\right)$ & 89.28 & 1.01 & 79.16 & 95.83 & 5.60 \\
Pod Length $(\mathrm{cm})\left(\mathrm{x}_{2}\right)$ & 15.36 & 0.55 & 10.94 & 20.14 & 17.67 \\
Pod Diameter $(\mathrm{mm})\left(\mathrm{x}_{3}\right)$ & 10.46 & 0.23 & 9.07 & 12.14 & 10.27 \\
Individual Pod Weight $(\mathrm{g})\left(\mathrm{x}_{4}\right)$ & 11.38 & 0.44 & 8.29 & 16.16 & 18.76 \\
Number of seed pod $^{-1}\left(\mathrm{x}_{5}\right)$ & 6.80 & 0.24 & 4.80 & 8.35 & 17.09 \\
Number of dry pod plant $^{-1}\left(\mathrm{x}_{6}\right)$ & 41.65 & 2.46 & 25.93 & 67.00 & 28.94 \\
Dry pod yield plant $^{-1}(\mathrm{~g})\left(\mathrm{x}_{7}\right)$ & 116.11 & 6.65 & 59.99 & 180.60 & 28.07 \\
${\text { 100 seed weight }(\mathrm{g})\left(\mathrm{x}_{8}\right)}^{\text {Seed yield (t/ha) }(\mathrm{y})}$ & 36.45 & 2.69 & 20.75 & 64.13 & 36.19 \\
\hline
\end{tabular}

Table 3. Mean squares of the 9 traits of French bean for the season 2016/2017

\begin{tabular}{|c|c|c|c|c|c|}
\hline SOV & Df & Germination (\%) & Pod length $(\mathrm{cm})$ & $\begin{array}{l}\text { Pod diameter } \\
(\mathrm{mm})\end{array}$ & $\begin{array}{l}\text { Individual pod weight } \\
(\mathrm{g})\end{array}$ \\
\hline Genotype (G) & 5 & $35.82 \mathrm{~ns}$ & $31.25 * * *$ & $0.19 * *$ & $5.75 * * *$ \\
\hline Replications & 3 & $1.74 \mathrm{~ns}$ & $2.43 *$ & $0.015 \mathrm{~ns}$ & $3.24 * *$ \\
\hline Error & 15 & 16.31 & 0.47 & 0.028 & 0.39 \\
\hline SOV & $\begin{array}{l}\text { Number of } \\
\text { seed pod }\end{array}$ & $\begin{array}{l}\text { Number of dry pod } \\
\text { plant }^{-1}\end{array}$ & $\begin{array}{c}\text { Dry pod yield plant } \\
{ }_{1}^{-}(\mathrm{g})\end{array}$ & Seed yield (t/ha) & 100 seed weight $(\mathrm{g})$ \\
\hline Genotype (G) & $4.75 * * *$ & $613.86 * *$ & $5456.6^{*}$ & $0.168 *$ & $847.78 * * *$ \\
\hline Replications & $0.62 \mathrm{~ns}$ & $608.12 * *$ & 2417.2ns & $0.066 \mathrm{~ns}$ & $26.37 \mathrm{~ns}$ \\
\hline Error & 0.36 & 79.40 & 1527.82 & 0.04 & 10.97 \\
\hline
\end{tabular}

***= Significant at $0.1 \%$ level. $* *=$ Significant at $1 \%$ level. * = Significant at $5 \%$ level. $\mathrm{ns}=$ Non-Significant

Table 4. Mean squares of the 9 traits of French bean for the season 2017/2018

\begin{tabular}{|c|c|c|c|c|c|}
\hline SOV & Df & Germination (\%) & Pod length $(\mathrm{cm})$ & $\begin{array}{l}\text { Pod diameter } \\
(\mathrm{mm})\end{array}$ & $\begin{array}{l}\text { Individual pod weight } \\
(\mathrm{g})\end{array}$ \\
\hline$\overline{\text { Genotype }(\mathrm{G})}$ & 5 & $242.33 *$ & 43.16 *** & $25.82 * * *$ & $43.95 * * *$ \\
\hline Replications & 3 & $53.38 \mathrm{~ns}$ & $0.02 \mathrm{~ns}$ & $0.175 \mathrm{~ns}$ & $15.55 * * *$ \\
\hline Error & 15 & 73.43 & 0.36 & 033 & 1.23 \\
\hline SOV & $\begin{array}{c}\text { Number of seed } \\
\text { pod }^{-1}\end{array}$ & $\begin{array}{l}\text { Number of dry pod } \\
\text { plant }^{-1}\end{array}$ & $\begin{array}{c}\text { Dry pod yield plant } \\
{ }^{1}(\mathrm{~g})\end{array}$ & Seed yield (t/ha) & 100 seed weight $(\mathrm{g})$ \\
\hline Genotype (G) & $7.48 * * *$ & $497.05 * *$ & $4447.9 *$ & $0.324 * *$ & $518.5 * * *$ \\
\hline Replications & $0.018 \mathrm{~ns}$ & $271.40 \mathrm{~ns}$ & $3154.3 \mathrm{~ns}$ & $0.132 \mathrm{~ns}$ & 27.64 \\
\hline Error & 0.145 & 88.65 & 1403.2 & 0.058 & 10.26 \\
\hline
\end{tabular}

***= Significant at $0.1 \%$ level. $* *=$ Significant at $1 \%$ level. $*=$ Significant at $5 \%$ level. ns $=$ Non-Significant 
Table 5. Mean squares of the 9 traits of French bean for the season 2018/2019

\begin{tabular}{|c|c|c|c|c|c|}
\hline SOV & Df & Germination $(\%)$ & Pod length $(\mathrm{cm})$ & $\begin{array}{l}\text { Pod diameter } \\
(\mathrm{mm})\end{array}$ & $\begin{array}{l}\text { Individual pod } \\
\text { weight }(\mathrm{g})\end{array}$ \\
\hline Genotype (G) & 5 & $127.02 *$ & $29.37 * * *$ & $2.06^{* * * *}$ & $15.63 * * *$ \\
\hline Replications & 3 & $42.05 \mathrm{~ns}$ & $1.165 \mathrm{~ns}$ & $0.433 \mathrm{~ns}$ & $0.29 \mathrm{~ns}$ \\
\hline Error & 15 & 38.78 & 0.637 & 0.201 & 1.38 \\
\hline SOV & $\begin{array}{l}\text { Number of seed } \\
\text { pod }^{-1}\end{array}$ & $\begin{array}{l}\text { Number of dry pod } \\
\text { plant }^{-1}\end{array}$ & $\begin{array}{l}\text { Dry pod yield plant }{ }^{-1} \\
(\mathrm{~g})\end{array}$ & $\begin{array}{l}\text { Seed yield } \\
\text { (t/ha) }\end{array}$ & 100 seed weight $(\mathrm{g})$ \\
\hline Genotype (G) & $8.83 * * *$ & $33.67 \mathrm{~ns}$ & $1781.52 *$ & $5.124 * * *$ & $721.86^{* * *}$ \\
\hline Replications & $0.74 \mathrm{~ns}$ & $59.76^{*}$ & 299.40ns & $0.467 \mathrm{~ns}$ & $20.88 * * *$ \\
\hline Error & 0.377 & 13.62 & 518.87 & 0.432 & 2.18 \\
\hline
\end{tabular}

\section{Analysis of Variance}

Statistical analysis according to the technique of analysis of variance (ANOVA) of randomized complete block design (RCBD) for successive three seasons for above mentioned traits are summarized in Tables 3, 4 and 5. Based on the results obtained, statistical analysis revealed that the genotypes included in the study for the season 2016/17 had a considerable amount of variation at $\mathrm{P} \leq 0.001, \mathrm{P} \leq 0.01$ and $\mathrm{P} \leq 0.05$ for all traits under study except germination (\%) which had significant variation $(P \leq 0.05)$. During the $2017 / 18$ season, statistical analysis revealed the significant variation at $\mathrm{P} \leq 0.001, \mathrm{P} \leq 0.01$ and $\mathrm{P} \leq 0.05$ for all the traits understudied. Likewise, during the season 2018/19, there was significant variation at $\mathrm{P} \leq 0.001$, $\mathrm{P} \leq 0.01$ and $\mathrm{P} \leq 0.05$ for all the traits understudied except the number of dry pods plant ${ }^{-1}$. It could be concluded that differences between French bean cultivars over the seasons may be due to genetic differences between cultivars and environmental effect indicating a considerable amount of variation present in germplasm and revealing a high level of diversity among the cultivars for these traits. This provides evidence for sufficient variability and selection of these traits can be useful for breeding purposes. Alemu et al. (2017) observed highly significant differences among the Snap bean genotypes with green pod yield and its components. Similarly, Razvi et al. (2018) reported significant differences among the genotypes in Common Bean for most of the studied morphological character indicating the existence of variability in the material.

\section{Simple Correlation and Regression Analysis}

Pearson Correlation statistics is a widely applicable evaluation method that effectively shows the relationship between two variables. According to the data presented in Table 6 , the correlation coefficient ( $\mathrm{r}$ ) for pod length, individual pod weight and number of seed pod $^{-1}$ were positive and significantly correlated with seed yield, $\mathrm{r}=$ $0.659 * * *, r=0.548^{* *}$ and $\mathrm{r}=0.459^{*}$, respectively (Table $6)$, indicating that increase in this character would increase the seed yield. Other traits including germination (\%), number of dry pod plant ${ }^{-1}$, dry pod yield pod plant ${ }^{-1}$ and 100 seed weight showed positive and non-significant effect suggesting as these traits increases, seed yield also increases. Tiwari and Singh (2019) recorded positive and non-significant correlation of 100 seed weight with seed yield $(r=0.017)$ in Faba bean. $p$ Likewise, pod diameter showed negative and non-significant effect revealing an increase in the value of pod diameter decreases the seed yield.
Positive and significant association ( $\mathrm{r}=0.659 * * *)$ between individual pod weight and seed yield (t/ha) revealed that an increase in individual pod weight will correspondingly increase seed yield ( $\mathrm{t} / \mathrm{ha}$ ). About $43.4 \%$ of total variability in seed yield ( $\mathrm{t} / \mathrm{ha}$ ) was due to its association with individual pod weight; while the regression coefficient indicated that $1 \mathrm{~g}$ increase in individual pod weight will simultaneously give an increase of $0.188 \mathrm{~g}$ in seed yield ( $\mathrm{t} / \mathrm{ha}$ ). The correlation between the number of seed pod $^{-1}$ and seed yield ( $\left.t / h a\right)$ showed significantly positive association $\left(\mathrm{r}=0.548^{* *}\right)$ which indicated that an increase in the number of seed pod $^{-1}$ will markedly increase seed yield ( $\mathrm{t} / \mathrm{ha}$ ). The coefficient of determination $\left(\mathrm{R}^{2}\right)$ revealed that $30 \%$ of total variability in seed yield pod $^{-1}$ was due to its association with number of seed pod $^{-1}$; while regression coefficient showed that a unit increase in number of seed pod $^{-1}$ will increase of $0.285 \mathrm{~g}$ in seed yield (t/ha). Likewise, the correlation between pod length and seed yield ( $t /$ ha) showed significantly positive association $(r=0.459 *)$ which indicated that an increase in pod length $(\mathrm{cm})$ will markedly an increase seed yield $(\mathrm{t} / \mathrm{ha})$. The coefficient of determination $\left(\mathrm{R}^{2}\right)$ revealed that $21.1 \%$ of total variability in seed yield pod $^{-1}$ was due to its association with pod length $(\mathrm{cm})$; while the regression coefficient showed that a unit increase in pod length $(\mathrm{cm})$ will increase $0.103 \mathrm{~g}$ in seed yield (t/ha). Among the various traits, individual pod weight had the strongest association with the seed yield, suggesting that this trait might be an important yield component and can be used to improve French bean. In addition to pod weight, the number of seed pod $^{-1}$ and pod length also had a strong positive correlation with seed yield. The similar positive correlation of individual seed weight and number of seeds pod $^{-1}$ were also found in common bean by Akhshi et al. (2015) and Sadeghi et al. (2011). Salehi et al. (2010) reported a significant and positive correlation of grain yield with the number of seeds plant ${ }^{-1}$, number of pods plant ${ }^{-1}$, and pod length. Similarly, Kamaluddin and Ahmed (2011) reported a positive correlation of the number of seeds pod ${ }^{-}$ ${ }^{1}$ with seed yield. The most effective factors in common bean were determined as plant height, number of pods, number of seed per pod and 1000 seed weight (Onder and Ozkaynak, 1994). Similarly, Cokkizgin et al. (2013) reported a positive and significant correlation of seed yield per plant with pod length $(r=0.51)$ and seed number per $\operatorname{pod}(\mathrm{r}=0.57)$. 
Table 6. Correlation (r), regression coefficients (b) and coefficient of determination $\left(\mathrm{R}^{2}\right)$ of various traits in French bean genotypes for the season $(2016-2018$

\begin{tabular}{l|ccc}
\hline \multicolumn{1}{c|}{ Character association } & $\begin{array}{c}\text { Correlation } \\
\text { coefficient (r) }\end{array}$ & $\begin{array}{c}\text { Regression } \\
\text { coefficient (b) }\end{array}$ & $\begin{array}{c}\text { Coefficient of } \\
\text { determination }\left(\mathrm{R}^{2}\right)\end{array}$ \\
\hline Germination (\%) vs seed yield (t/ha) & $0.353 \mathrm{~ns}$ & 0.043 & 0.125 \\
Pod Length (cm) vs seed yield (t/ha) & $0.459^{*}$ & 0.103 & 0.211 \\
Pod Diameter (mm) vs seed yield (t/ha) & $-0.025 \mathrm{~ns}$ & -0.014 & 0.0006 \\
Individual Pod Weight (g) vs seed yield (t/ha) & $0.659 * * *$ & 0.188 & 0.434 \\
Number of seed pod ${ }^{-1}$ vs seed yield (t/ha) & $0.548^{* *}$ & 0.285 & 0.300 \\
Number of dry pod plant ${ }^{-1}$ vs seed yield (t/ha) & $0.139 \mathrm{~ns}$ & 0.007 & 0.019 \\
Dry pod yield plant $^{-1}(\mathrm{~g})$ vs seed yield (t/ha) & $0.351 \mathrm{~ns}$ & 0.006 & 0.123 \\
100 seed weight (g) vs seed yield (t/ha) & $0.190 \mathrm{~ns}$ & 0.008 & 0.036 \\
\hline
\end{tabular}

Table 7. Path coefficient analysis of eight characters on seed yield in French bean for the season (2016- 2018)

\begin{tabular}{|c|c|c|c|c|c|c|c|c|c|}
\hline Traits & $\mathrm{X}_{1}$ & $\mathrm{X}_{2}$ & $\mathrm{X}_{3}$ & $\mathrm{X}_{4}$ & $\mathrm{X}_{5}$ & $\mathrm{X}_{6}$ & $\mathrm{X}_{7}$ & $\mathrm{X}_{8}$ & $\begin{array}{c}\text { Seed Yield } \\
\text { (t/ha) }\end{array}$ \\
\hline$\overline{\text { Germination }(\%)\left(\mathrm{x}_{1}\right)}$ & $(0.032)$ & 0.026 & 0.079 & 0.062 & -0.044 & -0.011 & -0.013 & 0.224 & $0.353 \mathrm{~ns}$ \\
\hline Pod Length $(\mathrm{cm})\left(\mathrm{x}_{2}\right)$ & -0.002 & $(-0.293)$ & -0.096 & 0.354 & 0.702 & 0.044 & 0.011 & -0.261 & $0.459 *$ \\
\hline Pod Diameter $(\mathrm{mm})\left(\mathrm{x}_{3}\right)$ & 0.015 & 0.173 & $(0.164)$ & -0.134 & -0.547 & -0.102 & -0.029 & 0.435 & $-0.025 n s$ \\
\hline Individual Pod Weight $(\mathrm{g})\left(\mathrm{x}_{4}\right)$ & 0.004 & -0.243 & -0.051 & $(0.429)$ & 0.628 & 0.020 & 0.015 & -0.145 & $0.659 * * *$ \\
\hline Number of seeds pod ${ }^{-1}\left(x_{5}\right)$ & -0.002 & -0.268 & -0.117 & 0.351 & $(0.767)$ & 0.077 & 0.027 & -0.287 & $0.548 * *$ \\
\hline Number of dry pod plant ${ }^{-1}\left(\mathrm{x}_{6}\right)$ & -0.002 & -0.076 & -0.097 & 0.051 & 0.346 & $(0.171)$ & 0.035 & -0.286 & $0.139 \mathrm{~ns}$ \\
\hline Dry pod yield plant ${ }^{-1}(\mathrm{~g})\left(\mathrm{x}_{7}\right)$ & -0.005 & -0.037 & -0.058 & 0.079 & 0.256 & 0.071 & $(0.083)$ & -0.039 & $0.351 \mathrm{~ns}$ \\
\hline 100 seed weight $(\mathrm{g})\left(\mathrm{x}_{8}\right)$ & 0.013 & 0.144 & 0.135 & -0.117 & -0.416 & -0.092 & -0.006 & $(0.530)$ & $0.190 \mathrm{~ns}$ \\
\hline
\end{tabular}

Italic and bold figures along the diagonal denote direct effects while regular figures denotes indirect effects; Residual Effect $=0.2703$

Table 8. Relative contribution (partial and model $\mathrm{R}^{2}$ ), regression coefficient (b), standard error (SE), t-value, variance inflation factor (VIF)

\begin{tabular}{c|l|ccccccc}
\hline Step & \multicolumn{1}{|c|}{ Variable Entered } & Partial R $^{2}$ & Model R $^{2}$ & B & SE & T & VIF & P-value \\
\hline 1 & Individual Pod Weight & 0.4349 & 0.4092 & 0.2226 & 0.0374 & 5.96 & 1.08 & 0.000 \\
2 & 100 Seed weight & 0.1483 & 0.1343 & 0.02798 & 0.00715 & 3.92 & 1.51 & 0.001 \\
3 & Number of dry pod per plant & 0.0990 & 0.0911 & 0.01891 & 0.00758 & 2.50 & 1.42 & 0.021 \\
\hline
\end{tabular}

Constant $=-2.855, \mathrm{R}^{2}=68.22 \% \mathrm{R}^{2}=63.46$ (adjusted)

\section{Path Coefficient Analysis}

The direct and indirect relationship among seed yield and components traits proposed through correlation and regression study was further analyzed through path coefficients. The estimates of the direct and indirect effect of eight attributes on seed yield are presented in Table 7. The most effective direct effect was exhibited by the number of seeds pod $^{-1}(0.767)$ followed by 100 seed weight (0.530) and individual pod weight (0.429). Among these traits, the number of seeds pod ${ }^{-1}$ and individual pod weight showed positive and significant correlation and 100 seed weight showed positive but non-significant correlation with seed yield. Similarly, the number of dry pods plant ${ }^{-1}$ $(0.171)$, dry pod yield plant $^{-1}(0.083)$ and germination percentage (0.032) also recorded positive direct effect but positive and non-significant correlation with seed yield. Pod diameter showed a positive direct effect $(0.164)$ on seed yield, but negative correlation which may be as a result of its negative effects via other traits. On the other hand, pod length had a negative direct effect on seed yield but its indirect effect through the number of seeds pod ${ }^{-1}$ and individual pod weight was high and positive. Also, it has a positive and significant correlation with seed yield which implies consideration of this trait in breeding work via indirect traits for achieving longer pod length is valuable. Genotypic residual effect $(0.2703)$ indicates that traits under study contribute $72.97 \%$ to the variability in seed yield. It indicates that few other traits which have not been studied here, need to be included to account fully for the variation in seed yield.

The results of path analysis of traits on seed yield reported by Akhshi et al. (2015) indicated that the pod weight recorded the highest direct and positive effect and 100 seed weight recorded the lowest and direct effect on seed yield. Yorgancilar et al. (2003) recorded the direct effect of the number of seeds per pod and 1000 seed weight on yield of pod. Number of pods/plants, 100 seed weight and pod length had a maximum positive direct effect on seed yield (Shahid and Kamaluddin, 2013).

\section{Stepwise Multiple Linear Regression}

To omit the effects of insignificant traits in the regression model on dependent variable seed yield, stepwise regression was used. In this analysis, seed yield $\left(\right.$ tha $\left.^{-1}\right)(\mathrm{Y})$ was considered as a dependent variable and other traits as independent variables. Accepted variables and their relative contributions are shown in Table 8.

The results showed individual pod weight, 100 seed weight and number of dry pods per plant with $\mathrm{R}^{2}=68.22 \%$ showed their overall contribution towards seed yield (Table 9 and Figure 1). The relative contributions for the 
traits individual pod weight, 100 seed weight and number of dry pod plant ${ }^{-1}$ in the total variations of seed yield was $43.49 \%, 14.83 \%$, and $9.90 \%$, respectively. As a result, based on the stepwise regression model following yield estimating equation was obtained.

$$
\mathrm{Y}=-2.85+0.22 \mathrm{x}_{4}+0.028 \mathrm{x}_{8}+0.019 \mathrm{x}_{6}
$$

Where,

$\mathrm{Y}, \mathrm{x}_{4}, \mathrm{x}_{6}$, and $\mathrm{x}_{8}$ are seed yield, individual pod weight, number of dry pods plant ${ }^{-1}$ and 100 seed weight, respectively.

The significant $R^{2}$ values in the regression equation indicate the effectiveness of these traits to increase the seed yield. Salehi et al (2010) suggested the number of pods per plant as the most effective factor on seed yield with $83.2 \%$ contribution on the total variations. Similarly, the number of pods per plant alone explained around $65 \%\left(\mathrm{R}^{2}=0.646\right)$ of variation in seed yield of faba bean (Tiwari and Singh, 2019). In another study, the pod weight, the seed number per pod and the 100 seed weight accounted for $99 \%$ of the total variation for seed yield (Akhshi et al., 2015). Therefore, these traits were considered the most effective components for seed yield. The unexplained variation $(31.78 \%)$ may be intrinsically due to genotype or due to the indirect effect of unobserved traits in yield. A positive regression coefficient of the three variables represents the mean increase in seed yield for an additional one unit increase for each of the variables. Thus, high seed yield of French bean cultivars can be obtained by selecting the breeding materials with high value of these traits.

Table 9. French bean traits identified as crucial in seed yield with each one of the used statistical techniques

\begin{tabular}{|c|c|c|c|c|c|}
\hline $\begin{array}{c}\text { Character/ Statistical } \\
\text { procedures }\end{array}$ & $\begin{array}{l}\text { Simple } \\
\text { correlation }\end{array}$ & $\begin{array}{l}\text { Simple Linear } \\
\text { regression }\end{array}$ & $\begin{array}{c}\text { Path } \\
\text { analysis }\end{array}$ & $\begin{array}{l}\text { Stepwise } \\
\text { regression }\end{array}$ & Frequency \\
\hline Germination $(\%)\left(\mathrm{x}_{1}\right)$ & & & & & 0 \\
\hline Pod Length $(\mathrm{cm})\left(\mathrm{x}_{2}\right)$ & $\checkmark$ & $\checkmark$ & & & 2 \\
\hline Pod Diameter $(\mathrm{mm})\left(\mathrm{x}_{3}\right)$ & & & & & 0 \\
\hline Individual Pod Weight $(\mathrm{g})\left(\mathrm{x}_{4}\right)$ & $\checkmark$ & $\checkmark$ & $\checkmark$ & $\checkmark$ & 4 \\
\hline Number of seed pod ${ }^{-1}\left(x_{5}\right)$ & $\checkmark$ & $\checkmark$ & $\checkmark$ & & 3 \\
\hline Number of dry pod plant ${ }^{-1}\left(\mathrm{x}_{6}\right)$ & & & & $\checkmark$ & 1 \\
\hline Dry pod yield plant ${ }^{-1}(\mathrm{~g})\left(\mathrm{x}_{7}\right)$ & & & & & 0 \\
\hline 100 seed weight $(\mathrm{g})\left(\mathrm{x}_{8}\right)$ & & & $\checkmark$ & $\checkmark$ & 2 \\
\hline
\end{tabular}

The statistical procedures determining the dependence relationship between seed yield and yield components of French bean showed that the individual pod weight $\left(\mathrm{x}_{4}\right)$, number of seeds $\operatorname{pod}^{-1}\left(\mathrm{x}_{5}\right), 100$ seed weight $\left(\mathrm{x}_{8}\right)$ and pod length $\left(\mathrm{x}_{2}\right)$ were the most effective traits to be considered while selecting these genotypes for breeding materials.

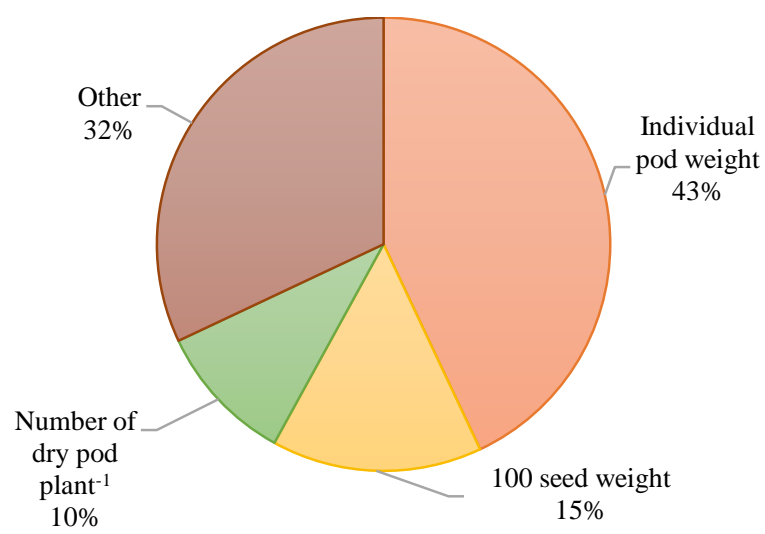

Figure 1. The relative contributions of yield components

\section{Conclusion}

This study has shown the existence of a considerable amount of variation among the genotypes for crop improvement. The multiple statistical techniques applied in this study displayed that simple correlation and regression analysis solely cannot distinguish direct result of genotype and indirect effect of component trait to seed yield. Therefore, it is necessary to use multivariate statistical methods such as multiple regression and pathway analysis to quantify relative importance of traits in screening genotypes for breeding program in French bean. Based on the results of this study, we arrive at the conclusion that individual variables affect seed yield directly or indirectly, positively or negatively, through each other. In the nutshell, based on the multiple statistical methods individual pod weight appeared to be the most effective contributor to the seed yield followed by the number of seed pod $^{-1}, 100$ seed weight, and pod length. Hence, four of these traits should be observed in detail for signs of change in developing high yielding cultivars for French bean.

\section{Acknowledgments}

The authors are grateful to Nepal Agricultural Research Council (NARC) for providing the materials for the study. Sincere thanks also go to the management team of Horticulture Research Station, Dailekh, lower technical staffs and labor which were involved during the entire production period of the experiment.

\section{References}

Akhshi N, Firouzabadi F, Cheghamirza K, Dorri H. 2015. Coefficient Analysis and Association between MorphoAgronomical Characters in Common Bean (Phaseolus vulgaris L.). Cercetari AgronomiceIn Moldova, 48(4):29-37, doi: 10.1515/cerce-2015-0050

Alemu Y, Alamirew S, Dessalegn L. 2017. Correlation and Path Analysis for Green Pod Yield and Its Components in Snap Bean (Phaseolus Vulgaris L.) Genotypes. International Journal of Research in Agriculture and Forestry, 4(1): 30-36

Ambachew D, Mekbib F, Asfaw A, Beebe S, Blair M. 2015. Trait associations in common bean genotypes grown under drought stress and field infestation by BSM bean fly. The Crop Journal, 3(4): 305-316, doi: 10.1016/j.cj.2015.01.006 
Cokkizgin A, Colkesen M, Idikut L, Ozsisli B, Girgel U. 2013. Determination of relationships between yield components in bean by using path coefficient. Greener Journal of AgriSciences, 3 (2): 085-089.

Doust J, Doust L, Eaton G. 1983. Sequential Yield Component Analysis and Models of Growth in Bush Bean (Phaseolus vulgaris L.). American Journal of Botany, 70(7): p.1063. doi: $10.2307 / 2442816$

Ejara E, Mohammed W, Amsalu B. 2017. Correlations and path coefficient analyses of yield and yield related traits in common bean accessions (Phaseolus vulgaris L.) at Abaya and Yabello, Southern Ethiopia. International Journal of Plant Breeding and Crop Science, 4 (2): 215-224.

FAO.2017. http://www.fao.org/faostat/en/\#data/QC

Ghobary HMM, Abd-Allah SAM. 2010. Correlation and path coefficient studies in common bean (Phaseolus vulgaris L.). Journal of Plant Production, 1(9): 21233-1239.

Gonçalves D, Barelli M, Oliveira T, Santos P, Silva C, Poletine J, Neves L. 2017. Genetic correlation and path analysis of common bean collected from Caceres Mato Grosso State, Brazil. Ciência Rural, 47(8), doi: 10.1590/0103$8478 \mathrm{cr} 20160815$

Gonçalves M, Correa A, Destro D, Souza L, Alves Sobrinho T. 2003. Correlations and path analysis of common bean grain yield and its primary components. Crop Breeding and Applied Biotechnology, 3(3): 217-222, doi:10.12702/19847033.v03n03a06

Kamaluddin, Ahmed S. 2011. Variability, correlation and path analysis for seed yield and yield related traits in common beans. Indian J. Hort. 68(1): 50-60.

Karasu A, Oz M. 2010. A study on coefficient analysis and association between agronomical characters in dry bean (Phaseolus vulgaris L.) Bulgarian Journal of Agricultural Science, 16(2): 203-211.

Neupane RK, Shrestha R,Vaidya ML, Bhattarai EM, Darai R. 2008. Agromorphological diversity in common bean (Phaseolus vulgaris L.) landraces of Jumla, Nepal, in: M.C. Kharkwal, (ed.), Proceedings of the Fourth International Food Legumes Research Conference, New Delhi, India, pp. 639-648.

Nimbalkar CA, Baviskar AP, Desai UT. 2002. Selection strategy for yield improvement in rajmash (Phaseolus vulgaris L.). Indian Journal of Genetics and Plant Breeding, 62 (4): 349-351.

Ojha R, Sarkar A, Aryal A, Rahul K.C., Poudel M.R., Pant KR, Shrestha J. 2018. Correlation and path coefficient analysis of wheat (Triticumaestivum L.) genotypes. Farming \& Management, 3(2). doi: 10.31830/2456-8724.2018.0002.19.
Onder M, Ozkaynak I. 1994. The effects of inoculation and nitrogen applications on the grain yield and some characteristics of dwarf dry bean varieties. Turkish Journal of Agriculture and Forestry, 18: 463-471.

Panchbhaiya A, Singh DK, Jain SK. 2017. Inter-characters association studies for morphological, yield and yield attributes in the germplasm of French bean (Phaseolus vulgaris L.) in Tarai region of Uttarakhand, India. Legume Research-An International Journal, 40(1): 196-199.

Raffi SA, Nath UK. 2004. Variability, heritability, genetic advance and relationships of yield and yield contributing characters in dry bean (Phaseolus vulgaris L.). Journal of Biological Sciences, 4: 157- 159.

Razvi M, Khan M, Bhat M, Ahmad M, Ganaie S, Sheikh F, et al. 2018. Morphological variability and phylogenetic analysis in Common bean (Phaseolus vulgaris L.). Legume Research an International Journal, (00), doi: 10.18805/lr-3421

Sadeghi A, Cheghamirza K, Dorri HR. 2011. The study of morphoagronomic traits relationship in common bean (Phaseolus vulgaris L.). Biharean Biologist 5(2): 102-108.

Salehi M, Faramarzi A, Mohebalipour N. 2010. Evaluation of different effective traits on seed yield of common bean (Phaseolus vulgaris L.) with path analysis. AmericanEurasian Journal of Agricultural \& Environmental Sciences, 9(1): 52-54.

ShahidA, Kamaluddin. 2013. Correlation and path analysis for agro-morphological traits in rajmash beans under BaramullaKashmir region. African Journal of Agricultural Research, 8(18): 2027-2032. doi: 10.5897/ajar2012.0014

Singh A, Singh DK. 2013. Genetic variability and character association analysis in French bean (Phaseolus vulgaris L.). Journal of Food Legumes, 26 (3\&4): 130-133.

Steel R, Torrie J, Dickey DA. 1997. Principles and Procedures of Statistics: A Biometrical Approach. 3rd ed. McGraw Hill Book Co. New York.

Tiwari JK, Singh AK. 2019. Principal component analysis for yield and yield traits in faba bean (ViciafabaL.). Journal of Food Legumes 32(1) :13-15.

Yorgancilar O, Kenar D, Şehirali S. 2003. The effect of nitrogen doses on yield and yield components of Bush bean varieties. Fifth Field Crops Congress (13-17 October, 2003), Diyarbakir, Turkey, 555-559. 